\title{
Evaluation of fecal smear methods for research on Cryptosporidium spp. oocysts in the feces of dairy calves
}

\section{Avaliação dos métodos de esfregaço fecal para a pesquisa de oocistos de Cryptosporidium spp. nas fezes de bezerros da bovinocultura de leite}

\author{
Ana Paula Molinari Candeias ${ }^{1 *}$; Gabrieli Maria Huff2; Adriana Fiorini Rosado \\ André Luis Vriesman Beninca ${ }^{1}$; Laura Zanella Souza'; Silvia Cristina Osaki4; \\ Nelson Luis Mello Fernandes ${ }^{4}$
}

\section{Highlights}

Analysis revealed higher sensitivity when centrifugal sedimentation was used.

Molecular analysis is indicated to confirm cases of Cryptosporidium spp. in calves.

The sequencing results made it possible to identify three Cryptosporidium spp.

The specificities of the used primers must be further studied.

\begin{abstract}
The objective of this study is to compare the direct fecal smear (DFS) and centrifugal sedimentation (CS) methods in the detection of Cryptosporidium spp. oocysts in fecal samples of dairy calves. One hundred and fourteen fecal samples were collected from calves aged up to six months from 10 dairy farms located in Palotina and Francisco Alves, Paraná, Brazil. The microscopic analysis revealed the presence of Cryptosporidium spp. oocysts in 51.75\% (59/114) of the samples in both methods. In CS, 48.25\% (55/114) of the samples were positive, while in DFS slides, only $6.14 \%(7 / 114)$ were positive. Only 4 samples were positive exclusively in DFS. To ensure that there were no false-negative results in the microscopic analysis, the 55 samples that were negative in both DFS and CS were selected for molecular analysis using the nested PCR (nPCR). Of these 55 samples, 24\% (13/55) were positive and forwarded for sequencing part of the genome, which made it possible to identify C. parvum, C. bovis and C. ryanae. Besides the characterization

1 Master's student of the Graduate Program in Animal Science, Universidade Federal do Paraná, UFPR, Palotina, PR, Brazil. E-mail: anapmolinaric@gmail.com; drebeninca@gmail.com; laurazanellasouza@gmail.com

2 Undergraduate student in Bioprocess Engineering and Biotechnology, UFPR, Palotina, PR, Brazil. E-mail: gabrielihuff98@gmail.com

3 Profa Dra from the Graduate Program in Animal Science, Department of Biosciences, UFPR, Palotina, PR, Brazil. E-mail: drifiorini@gmail.com

4 Profs. Drs. from the Graduate Program in Animal Science, Department of Veterinary Sciences, UFPR, Palotina, PR, Brazil. E-mail: sil_osaki@ufpr.br; nlmfernandes@gmail.com

* Author for correspondence
\end{abstract}

Received: May 24, 2021 - Approved: Nov. 19, 2021 
of the Cryptosporidium species, it was possible to identify bacteria of the genus Acinetobacter interfering directly in the analyzed samples. The microscopic analysis also revealed higher sensitivity when CS was used to make the fecal smears. However, some samples that were negative in this technique had positive PCR results. Thus, molecular analysis is indicated to confirm cases of Cryptosporidium spp. Further studies are necessary to prove the specificities of the used primers since the results obtained in nPCR were positive for the protozoan but, when genetic sequencing was performed, Acinetobacter spp. was identified.

Key words: Nested PCR. Oocysts. Protozoan. Ziehl-Neeslsen.

\section{Resumo}

O objetivo deste trabalho foi comparar os métodos de esfregaço fecal direto (DFS) e centrífugo sedimentação (CS) para a pesquisa de oocistos de Cryptosporidium spp. em amostras fecais de bezerros leiteiros. Foram coletadas 114 amostras fecais de bezerros com até seis meses de idade, provenientes de dez propriedades leiteiras localizadas nos municípios de Palotina e Francisco Alves, Paraná. Por meio da análise microscópica, foi possível observar oocistos de Cryptosporidium spp. em 51,75\% (59/114) das amostras. Pelo método da CS foi identificada positividade em 48,25\% (55/114) das amostras, enquanto nas lâminas pelo método do esfregaço fecal direto (DFS), apenas 6,14\% (7/114) foram positivas. Somente 4 amostras foram positivas exclusivamente no método do DFS. Para assegurar que na análise microscópica não houvesse resultados falso-negativos, as 55 amostras negativas para os dois métodos de confecção de lâminas (DFS e CS) foram selecionadas para análise molecular por meio da técnica de Nested PCR. Das 55 amostras submetidas a nPCR, 24\% (13/55) apresentaram-se positivas e foram encaminhadas para o sequenciamento genético de uma porção do genoma, o qual possibilitou identificar as espécies de C. parvum, C. bovis e C. ryanae. Além da caracterização das espécies de Cryptosporidium, foi possível identificar a presença de bactérias do gênero Acinetobacter interferindo diretamente nas amostras analisadas. A análise microscópica revelou maior sensibilidade quando o método de CS foi usado para a confecção dos esfregaços fecais, entretanto, amostras negativas por meio dessa metodologia apresentaram resultados positivos na nPCR. Desta forma, para a confirmação dos casos de Cryptosporidium spp., é indicado a realização da análise molecular. Novos estudos são necessários para se comprovar a especificidade dos primers utilizados, uma vez que na nPCR o resultado obtido foi positivo, porém ao realizar o sequenciamento genético houve a identificação de Acinetobacter spp.

Palavras-chave: Nested-PCR. Oocistos. Protozoário. Ziehl-Neelsen.

\section{Introduction}

Cryptosporidiosis is caused by protozoa of the genus Cryptosporidium, which infect a wide range of hosts, such as mammals, birds, reptiles, fish, amphibians, and humans (Fayer, 2010). This infection may lead to significant economic losses, with the decrease of the zootechnical index, due to growth retardation, expenses on medication, and mortality (Santín, Trout, \& Fayer, 2008). In calves, neonatal diarrhea caused by these protozoa is a major cause of morbidity and mortality worldwide, especially in animals aged one month old or younger (Ouakli et al., 2018).

Bovine neonatal diarrhea can result from individual or associated action of 
certain pathogens, including Escherichia coli, rotavirus, coronavirus, and protozoa of the genera Giardia spp., Eimeira spp., and Cryptosporidium spp. (Chagas, 2015). Among the identified Cryptosporidium species, C. parvum stands out as the main agent responsible for diarrhea in newborn calves around the world and is also important due to its high zoonotic potential. Other zoonotic species worth metioning are C. meleagridis (common in poultry), C. cuniculus (found in rabbit species), and C. ubiquitum (commonly found in sheep) (Robertson, Johansen, Kifleyohannes, Efunshile, \& Terefe, 2020).

Calves are reservoir hosts of some Cryptosporidium spp., and contact with these animals was previously associated with human cryptosporidiosis (Reif, Wimmer, Smith, Dargatz, \& Cheney, 1989). Case-control studies conducted in the United States showed that contact of humans with cattle is a risk factor for cryptosporidiosis (Roy et al., 2004).

According to the systematic analysis of the Global Burden of Disease Study (Abubakar, Tillmann, \& Banerjee, 2013), Cryptosporidium spp. are responsible for 41,000 human deaths, ranking third in deaths caused by parasitic infections in 2013. C. parvum is a zoonotic species that widely infects many mammal species. Although its infection causes high morbidity and mortality in immunocompromised persons and calves, C. parvum remains a neglected disease (Fereig, Abdelbaky, \& Nishikawa, 2018). C. hominis, in turn, has been recently reported in calves, thus suggesting that its presence in these animals was underestimated. The rare C. hominis infection in animals disclosed in the recent reports may have occurred through the ingestion of contaminated feces of children by the animals (Razakandrainibe et al., 2018).

There is a wide variety of methods used in the diagnosis of Cryptosporidium spp., including immunodiagnostics, molecular techniques, and direct microscopic detection of oocysts (Bowman, 2010). The modified Ziehl-Neelsen stain for fecal smears provides effective visualization of oocysts and has already been considered the gold standard for diagnosis. Over time several techniques have been analyzed, among them direct immunofluorescence, which is currently used as a standard for direct diagnosis (Mammeri et al., 2019; Miambo et al., 2019). However, microscopic methods do not allow the characterization of Cryptosporidium spp. (Rigo \& Franco, 2002). Thus, it is necessary to use molecular techniques such as polymerase chain reaction (PCR). PCR can distinguish Cryptosporidium species and genotypes and presents high specificity and sensitivity (Miambo et al., 2019).

Although several species and genotypes of Cryptosporidium have been reported in humans, $C$. hominis and $C$. parvum are responsible for most infections. $C$. parvum, C. bovis, C. andersoni, and C. ryanae are the main species that affect cattle, which are considered important reservoir hosts of zoonotic infections (Xiao, 2010; Ryan, Fayer, \& Xiao, 2014). Molecular studies in China suggest that some C. meleagridis subtypes can be cross-transmissible between chickens and humans. Thus, this avian species is a potential reservoir host of zoonotic Cryptosporidium species, which was also identified in two other mammal species: minks and calves (Liao et al., 2018; Liu, Gong, Liu, Shen, \& Wu, 2020). Cryptosporidium spp. is the most common agent detected in animals infected with bovine neonatal diarrhea and is associated 
with clinical disease in newborn calves, while animals over six weeks of age present the asymptomatic phase of the disease, but also eliminate oocysts in their feces (Thomson, Hamilton, \& Hope, 2017).

The objective of this study is to compare the direct fecal smear (DFS) and centrifugal sedimentation (CS) methods in the detection of Cryptosporidium spp. oocysts in fecal samples of dairy calves.

\section{Materials and Methods}

\section{Ethics committee}

This study follows the Ethical Principles of Animal Experimentation and was approved by the Ethics Committee on Animal Use (CEUA) of the Federal University of Paraná (UFPR, protocol number 39/2019).

\section{Sample collection}

Fecal samples of 114 calves aged up to six months were collected from 10 randomly chosen dairy farms located in the municipalities of Francisco Alves and Palotina, Paraná. The samples were collected directly from the rectal ampoule of the animals and then identified, stored in sterile vessels, and kept refrigerated until processing.

\section{Microscopy}

Slides were prepared for microscopic analysis using two methods: DFS and CS, both stained with the modified Ziehl-Neelsen method (Ortolani, 2000). In DFS, a thin layer of feces was placed with the aid of a Swaab on a microscope slide and left to dry. To prepare the slides with the content resulting from CS, about $5 \mathrm{~g}$ of stool was diluted with approximately $40 \mathrm{~mL}$ of water. After homogenization, it the solution was filtered through a sieve and gauze and transferred to a Falcon tube for centrifugation $(2000 \mathrm{~g} /$ 2 min). The supernatant was discarded and, with the aid of a Pasteur pipette, a portion of the sedimented content $(2-3 \mathrm{~mL})$ was collected to prepare the thin smear, which was then left to dry. After drying, the slides at room temperature were fixed in methanol for $5 \mathrm{~min}$ and stained with phenolic fuchsin for 20 min. The slides were washed in running water, stained, and rinsed again. Then the smears were counterstained with methylene blue. After a final wash in tap water, the slides were dried to be examined under the microscope with immersion oil at $1000 x$ magnification. The staining of the fecal smears was performed simultaneously and respecting the action time of the dyes.

\section{DNA extraction and nPCR amplification}

To ensure that there were no falsenegative results when the slide preparation methods were compared, the samples that were negative in both DFS and CS during the microscopic analysis were selected for molecular analysis. The selected samples were submitted to clarification, DNA extraction, and nPCR, following Osaki et al. (2013) and using the primers proposed by Xiao et al. (1999).

At the end of clarification, $1 \mathrm{~mL}$ of lysis buffer (ChargeSwitch ${ }^{\circledR}$ ) was added to each sample and submitted to 15 cycles of freezing and thawing, as determined by Osaki et al. (2013). The remaining DNA 
extraction steps were followed according to the protocol provided by the manufacturer of the ChargeSwitch ${ }^{\circledR}$ gDNA Mini Tissue Kit (Invitrogen). DNA was eluted in $250 \mu \mathrm{L}$ of Elution Buffer (E5).

For polymerase chain reaction (PCR) and nested PCR (nPCR), the 18 SSU rRNA region was selected as the target sequence for DNA amplification, and the expected fragment was 826-864 bp. The primers used were XIAF/XIAR (5'TTCTAGAGCTAATACAT GCG3'/5'CCCATTTCCTTCGAAACAGGA3') (Xiao et al., 1999). The reaction was carried out with a final volume of $25 \mu \mathrm{L}$, containing Taq Pol Master Mix 2X Green (Cellco), 10 $\mu \mathrm{M}$ of each primer, and DNA, with initial denaturation at $94{ }^{\circ} \mathrm{C}$ for $3 \mathrm{~min}$ and 35 cycles at $94{ }^{\circ} \mathrm{C}$ for $45 \mathrm{sec}, 55^{\circ} \mathrm{C}$ for $45 \mathrm{sec}$ and $72^{\circ} \mathrm{C}$ for $1 \mathrm{~min}$ and a final extension at $72{ }^{\circ} \mathrm{C}$ for $7 \mathrm{~min}$. The products were analyzed by $\mathrm{nPCR}$ using XIA2F and XIA2R (5'GGAAGGGTTGTATTTATTAG ATAAAG3'/5'AAGGAGTAAGGAACAACCTC CA3') with initial denaturation at $94{ }^{\circ} \mathrm{C}$ for 1 $\min , 40$ cycles at $94^{\circ} \mathrm{C}$ for $30 \mathrm{sec}, 58^{\circ} \mathrm{C}$ at 1 min and $30 \mathrm{sec}$ and $72^{\circ} \mathrm{C}$ at 2 min and a final extension at $72{ }^{\circ} \mathrm{C}$ for $7 \mathrm{~min}$. The amplified products were subjected to $1.6 \%$ agarose gel electrophoresis. The positive controls were obtained from previously sequenced samples with high similarity results for Cryptosporidium parvum, provided by the Laboratory of Parasitic Diseases at the Federal University of Paraná (UFPR). Autoclaved ultrapure water was used as a negative control.

\section{Sequencing}

In order to determine the Cryptosporidium species circulating in the environment, samples identified as positive in $\mathrm{nPCR}$ were selected for DNA sequencing. The automated sequencer AB 3500 Genetic Analyzer equipped with $50 \mathrm{~cm}$ capillaries and POP7 polymer (Applied Biosystems) was used. The DNA templates were labeled using 2.5 pmol of each primer, XIA2F and XIA2R (5'-GGAAGGGTTGTATTTATTAGATAAAG-3' '/5'-AAGGAGTAAGGAACAACCTCCA-3') and $0.5 \mu \mathrm{L}$ of Big Dye Terminator reagent v3.1 Cycle Sequencing Standard (Applied Biosystems) in a final volume of $10 \mu \mathrm{L}$. The labeling reactions were performed in an LGC XP Cycler with an initial denaturation step at $96{ }^{\circ} \mathrm{C}$ for 3 min followed by 25 cycles of $96^{\circ} \mathrm{C}$ for $10 \mathrm{sec}, 55^{\circ} \mathrm{C}$ for $5 \mathrm{sec}$ and 60 ${ }^{\circ} \mathrm{C}$ for $4 \mathrm{~min}$. Once labeled, the samples were purified by precipitation with $75 \%$ isopropanol and washing with $60 \%$ ethanol. The precipitated products were diluted in 10 $\mu \mathrm{L}$ of $\mathrm{Hi}-\mathrm{Fi}$ formamide (Applied Biosystems), denatured at $95^{\circ} \mathrm{C}$ for $5 \mathrm{~min}$, cooled on ice for $5 \mathrm{~min}$, and electroinjected into an automated sequencer. Sequencing data were collected using the Data Collection 2 program (Applied Biosystems) with Dye Set "Z" parameters; Mobility File "KB_3500_POP7_BDTv3.mob"; BioLIMS Project "3500_Project1"; Run Module 1 "FastSeq50_POP7_50 cm_cfv_100"; and Analysis Module 1 "BC-3500SR_Seq_FASTA. saz".

\section{Results and Discussion}

The microscopic analysis of the fecal smear slides revealed 59 (51.75\%) protozoanpositive animals. All these animals were aged up to six months (Table 1). Cryptosporidium spp. oocysts were visualized only in $7(6,14 \%)$ of the 114 smear preparations in DFS, whereas in CS, 55 (48.25\%) slides allowed 
the visualization of oocysts (Figure 1). Only 3 samples were positive in both methods. The visualized oocysts measured from 2.3 $\mu \mathrm{m}$ to $3.76 \mu \mathrm{m}$, similar to the results found by Teixeira, Almeida and Oliveira (2008) and Xiao et al. (2002). All 10 analyzed farms had at least one positive animal, and in $60 \%$ of them, the diagnosis was possible only in CS.

As 4 samples were positive in DFS and were not identified in CS, which is considered much more sensitive, we decided to perform the molecular analysis of the samples. We adopted nPCR for the negative samples to guarantee that they were really negative as indicated in the microscopy and thus prove the diagnostic efficiency of the two compared techniques. Of the 55 samples that were negative in the microscopic analysis using both DFS and CS, 13 samples (23.64\%) were positive for Cryptosporidium spp. (Figure 2) in the molecular analysis.

Table 1

Results of the diagnosis of Cryptosporidium spp., obtained by fecal smear techniques, according to the age of dairy calves on farms in the municipalities of Francisco Alves and Palotina / PR

\begin{tabular}{ccccccc}
\multirow{2}{*}{ Dairy property } & \multicolumn{2}{c}{ 0-2 months } & \multicolumn{2}{c}{ Up to 4 months } & \multicolumn{2}{c}{ Up to 6 months } \\
\cline { 2 - 7 } & Positive & Negative & Positive & Negative & Positive & Negative \\
\hline 1 & 0 & 0 & 0 & 0 & 3 & 6 \\
3 & 2 & 4 & 4 & 7 & 1 & 0 \\
4 & 3 & 2 & 0 & 0 & 2 & 1 \\
5 & 0 & 3 & 2 & 2 & 2 & 0 \\
6 & 4 & 1 & 6 & 0 & 4 & 2 \\
7 & 4 & 0 & 2 & 0 & 2 & 0 \\
8 & 7 & 8 & 1 & 0 & 0 & 0 \\
9 & 7 & 3 & 0 & 0 & 0 & 0 \\
10 & 0 & 2 & 2 & 1 & 0 & 3 \\
Total & 1 & 3 & 0 & 5 & 0 & 2 \\
\hline
\end{tabular}




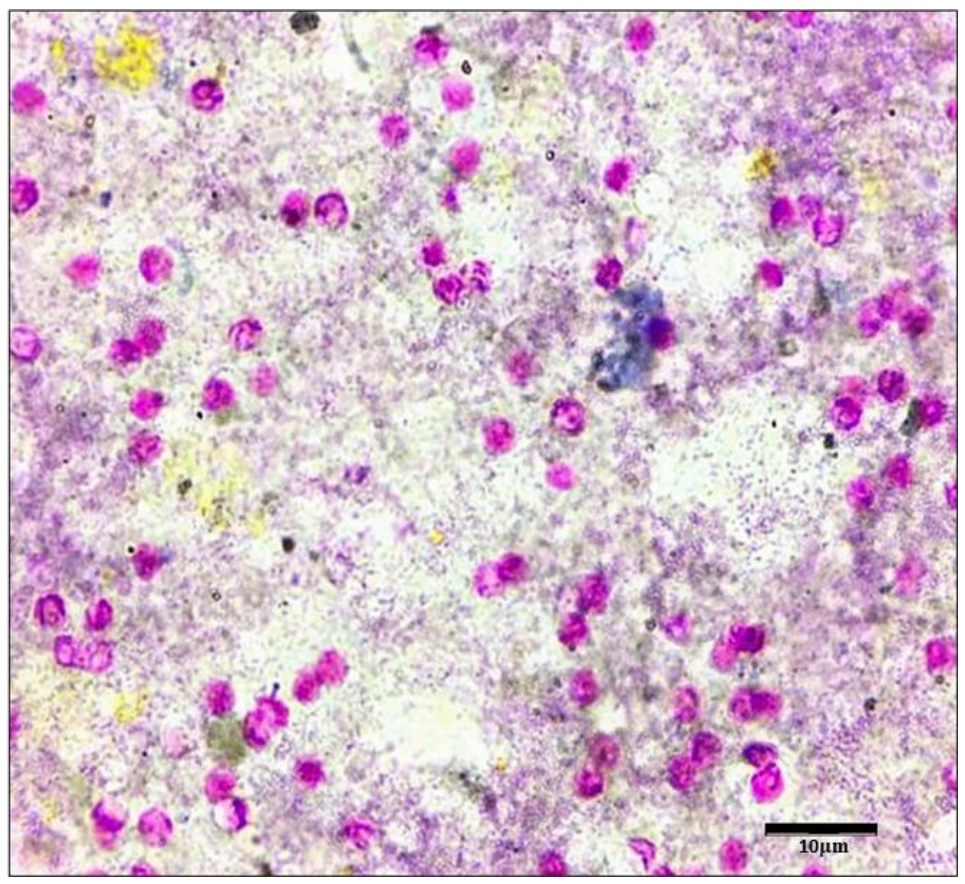

Figure 1. Oocysts of Cryptosporidium spp. (arrow) identified in a slide made using the centrifugal sedimentation (CS) technique and stained using the modified Ziehl-Neelsen method (1000x magnification).

\section{Percentage of false negative samples detected by nPCR}

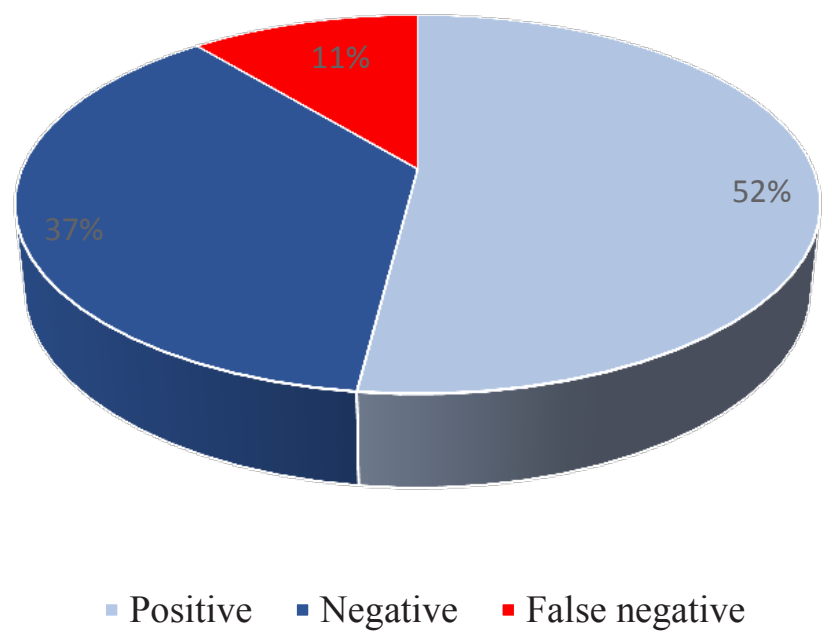

Figure 2. Percentage of false negative results for the detection of Cryptosporidium spp. in samples with negative microscopy results, but identified as positive by the molecular technique nPCR, in samples of dairy calves. 
In the literature there is no consensus on the gold standard for identification of Cryptosporidium spp., so the nPCR was used as the standard to prove the negativity of the analyzed samples. Nested PCR is a highly sensitive and specific molecular method used in the diagnosis of cryptosporidiosis (Abdelsalam, Sarhan \& Hanafy, 2017). This method amplifies binding sites by using two primer combinations in two reactions. The second reaction amplifies a secondary target within the first product, increasing the specificity of the results (Rahman, Uddin, Sultana, Moue, \& Setu, 2013). In the present study, microscopic tests showed a sensitivity of $81.94 \%$, but this percentage depends directly on the methodology used for the microscopic diagnosis and on the technician's capacity for identification.

The samples identified as positive in nPCR were selected for sequencing, and the result made it possible to identify the $C$. bovis, C. parvum, and C. ryanae species.

At least 6 Cryptosporidium species have been reported in cattle: $C$. parvum, $C$. bovis, C. ryanae, C. andersoni, C. ubiquitum, and C. hominis (Björkman et al., 2015; Razakandrainibe et al., 2018). C. hominis infection has been considered restricted to human beings and underestimated in calves. In France, a study conducted with symptomatic and asymptomatic animals aged three to seven weeks from farms located in five regions of the country identified 15 calves infected with C. hominis (Razakandrainibe et al., 2018).
Several studies have shown that there is an age-associated pattern related to the occurrence of the main Cryptosporidium species. In cattle, while C. parvum was found mainly in pre-weaned calves (aged up to two months), C. bovis and C. ryanae especially infected weaned calves and young adult animals, and $C$. andersoni mainly affected adult animals (Santín et al., 2004; Fayer, Santín, \& Trout, 2007; Robertson, Björkman, Axén, \& Fayer, 2014).

Regarding the age group and species found, the animals identified with $C$. parvum were between one and two months old, corroborating the data found by Santín et al. (2004), Fayer et al. (2007), and Matos et al. (2019). C. ryanae was identified in three samples from animals between two and four months of age, similar to the findings of Matos et al. (2019). However, other authors found this species in calves younger than one month of age (Wegayehu et al., 2016; Li et al., 2019). C. bovis has a higher incidence of infection in weaned animals (aged two to three months) (Santín et al., 2004; Fayer et al., 2007).

According to Wegayehu et al. (2016), C. bovis and C. ryanae infect animals of the same age group, with a higher occurrence of infection in post-weaned animals and a higher prevalence of $C$. bovis. However, in studies conducted in China by Cai et al. (2017), C. bovis was identified in pre-weaned animals (aged up to two months), similar to the present study, in which $C$. bovis infection was detected in a one-month-old animal (Table 2). 


\section{Table 2}

Identification of Cryptosporidium species according to the age of each animal, percentage of identity compared to GenBank sequences of isolates of the present work

\begin{tabular}{cccc|}
\hline \multicolumn{4}{c}{ SSU rRNA 18 Region Sequencing } \\
\hline Species identified & Age animal (months) & GenBank accession & $\begin{array}{c}\text { Similarity with GenBank } \\
\text { (accession number) }\end{array}$ \\
\hline C. bovis & 1 & OK614101 & $97,41 \%$ (MF671877.1) \\
C. parvum & 1 & OK638973 & $88,73 \%$ (GQ983351.1) \\
& 2 & OK638974 & $91,81 \%($ MK347430.1) \\
C. ryanae & 1 & OK638972 & $95,36 \%$ (AH006572.2) \\
& 2 & OK638970 & $92,22 \%($ KT922234.1) \\
& 4 & OK638969 & $99,87 \%($ MF671873.1) \\
& 4 & OK638971 & $99,36 \%($ MF671873.1)
\end{tabular}

Besides the characterization of Cryptosporidium species, the sequencing made it possible to identify bacteria of the genus Acinetobacter interfering directly in the analyzed samples. The genetic sequencing of Acinetobacter species was applied in BLAST, resulting in an $85-87 \%$ percentual of identity of the agent identification (Table 3).

\section{Table 3}

Bacteria of the genus Acinetobacter identified in sequencing of genetic material, extracted from fecal samples of dairy cattle, submitted to the search for oocysts of Cryptosporidium spp

\begin{tabular}{|ccc|}
\hline \multicolumn{2}{c|}{ Sequencing } \\
\hline Species identified & Similarity with GenBank & Accession number of GenBank sequences \\
\hline \multirow{3}{*}{ Acinetobacter schindleri } & $85,19 \%$ & CP044463.1 \\
& $87,56 \%$ & CP044463.1 \\
& $87,13 \%$ & CP044463.1 \\
Total & $87,59 \%$ & CP044463.1 \\
\hline
\end{tabular}

The identification of Acinetobacter bacteria indicates the presence of DNA of this agent in the samples. Bioinformatics allowed to identify about 100 bp similar between the sequences of Cryptosporidium spp. and Acinetobacter spp. where the used primers bind (Figure 3). 

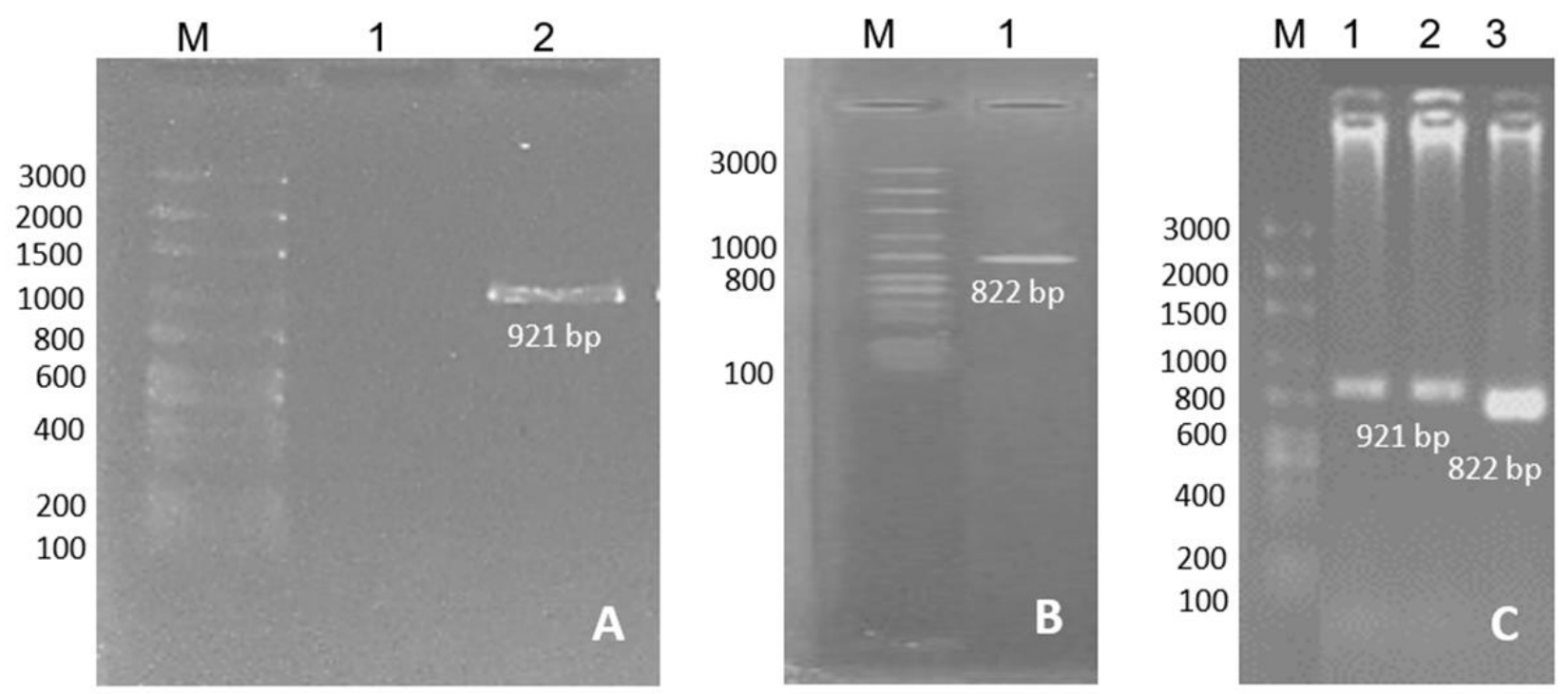

Figure 3. Agarose electrophoresis gel of nPCR products of Acinetobacter spp. and C. ryanae using Cryptosporidium primers.

A) M: Molecular size marker (3kb); 1: negative control; 2: $921 \mathrm{bp}$ amplicon of extracted genomic DNA of an Acinetobacter spp. isolate. B) M: Molecular size marker (3kb); 1: 822 bp amplicon of sample identified as C. ryanae. C) M: Molecular size marker (3kb); 1 and 2: 921 bp amplicon of sample identified as Acinetobacter schindleri 3: 822 bp amplicon of sample identified as C. ryanae.

The obtained sequence was found in an Acinetobacter spp. genome (NZ CP025618.2) obtained from GenBank and do not correspond to ribosomal sequence. Therefore, when the primers annealing sequences were found, we could note that they presented some minor base variations in relation to the Cryptosporidium primer sequences, indicating that even with these small differences, the PCR amplification was possible. Of the 13 samples that were positive in nPCR, 6 showed greater similarity with Acinetobacter spp., which could suggest false-positive results for the diagnosis of Cryptosporidium spp.

\section{Conclusion}

The slide preparation methods used in the microscopic analysis revealed greater specificity when CS was used. However, CS cannot be considered a gold standard test, as negative samples in this methodology showed positive results for Cryptosporidium spp. Thus, to confirm cases of Cryptosporidium spp. in cattle, molecular analysis is suggested as a diagnostic standard.

As a diagnostic proposal, nPCR needs improvement regarding the selection of new primers, since those proposed in this study identified other agents, yielding false-positive results. 


\section{References}

Abdelsalam, I. M., Sarhan, R. M., \& Hanafy, M. A. (2017). The impact of different copropreservation conditions on molecular detection of Cryptosporidium Species. Iranian Journal for Parasitology, 12(2), 274-283.

Abubakar, I. I., Tillmann, T., \& Banerjee, A. (2013). Global, regional, and national agesex specific all-cause and cause-specific mortality for 240 causes of death, 19902013: a systematic analysis for the Global Burden of Disease Study 2013. The Lancet, 385(9963), 117-171. doi: 10.1016/ s0140-6736(14)61682-2

Björkman, C., Lindström, L., Oweson, C., Ahola, H., Troell, K., \& Axén, C. (2018). Cryptosporidium infections in suckler herd beef calves. Parasitology, 142(8), 11081114. doi: $10.1017 /$ S0031182015000426

Bowman, D. D. (2010). Diagnóstico parasitológico. In D. D. Bowman (Ed.), Parasitologia veterinária de Georgis (9a ed., pp. 279-351). São Paulo: SaundersElsevier.

Cai, M., Guo, Y., Pan, B., Li, N., Wang, X., Tang, C., Xiao L. (2017). Longitudinal monitoring of Cryptosporidium species in pre-weaned dairy calves on five farms in Shanghai, China. Veterinary Parasitology, 241(1), 1419. doi: 10.1016/j.vetpar.2017.05.005

Chagas, A. C. S. (2015). Diarreia em bezerros leiteiros lactantes: a doença e o manejo em diferentes unidades da EMBRAPA. São Carlos: EMBRAPA Pecuária SudesteDocumentos (INFOTECA-E). Recuperado de https://www.infoteca.cnptia.embrapa. br/infoteca/bitstream/doc/1035039/1/ Documentos120.pdf
Fayer, R. (2010). Taxonomy and species delimitation in Cryptosporidium. Experimental Parasitology, 124(1), 90-97. doi: 10.1016/j.exppara.2009.03.005

Fayer, R., Santin, M., \& Trout, J. M. (2007). Prevalence of Cryptosporidium species and genotypes in mature dairy cattle on farms in eastern United States compared withyounger cattle from the same locations. Veterinary Parasitology, 145(3-4), 260-266. doi: 10.1016/j.vetpar. 2006.12.009

Fereig, R. M., Abdelbaky, H. H., Ihara, F., \& Nishikawa, Y. (2018). Development and evaluation of the first immunochromatographic test that can detect specific antibodies against Cryptosporidium parvum. Acta Tropica, 185(1), 349-356. doi: 10.1016/j. actatropica.2018.06.019

Li, N., Wang, R., Cai, M., Jiang, W., Feng, Y., \&Xiao, L. (2019). Outbreak of cryptosporidiosis due to Cryptosporidium parvum subtype IIdA19G1 in neonatal calves on a dairy farm in China. International Journal for Parasitology, 49(7), 569-577. doi: 10. 1016/j.ijpara.2019.02.006

Liao, C., Wang, T., Koehler, A. V., Fan, Y., Hu, M., \& Gasser, R. B. (2018). Molecular investigation of Cryptosporidium in farmed chickens in Hubei Province, China, identifies 'zoonotic' subtypes of C. meleagridis. Parasites \& Vectors, 11(1), 484. doi: 10.1186/s13071-018-3056-5

Liu, A., Gong, B., Liu, X., Shen, Y., \& Wu, Y. (2020). A retrospective epidemiological analysis of human Cryptosporidium infection in China during the past three decades (1987-2018). PLOS Neglected Tropical Diseases, 14(3), e0008146. doi: 10.1371/ journal.pntd.0008146 
Mammeri, M., Chevillot, A., Chenafi, I., Thomas, M., Julien, C., Vallée, I.,... Adjou, K.T. (2019). Molecular characterization of Cryptosporidium isolates from diarrheal dairy calves in France. Veterinary Parasitology: Regional Studies and Reports, 18(1),100323. doi: 10.1016/j. vprsr.2019.100323

Matos, L. V. S. de, Silveira, L. da Neto, Oliveira, B. C. M., Makatu, M. Y., Pierucci, J. C., Viol, M. A., Bresciani, K. D. S. (2019). Molecular characterization of Cryptosporidium in calves from rural settlements in the Northwest region of the state of São Paulo, Brazil. Semina: Ciências Agrárias, 40(1), 491-496. doi: 10.5433/1679-0359.2019v40n1p491

Miambo, R. D., Laitela, B., Malatji, M. P., Santana Afonso, S. M. de, Júnior, A. P., Lindh, J., \& Mukaratirwa, S. (2019). Prevalence of Giardia and Cryptosporidium in young livestock and dogs in Magude District of Maputo Province, Mozambique. Onderstepoort Journal of Veterinary Research, 86(1), e1-e6. doi: 10.4102/ojvr. v86i1.1709

Ortolani, E. L. (2000). Standardization of the modified Ziehl-Neelsen technique to stain oocysts of Cryptosporidium sp. Brazilian Journal of Veterinary Parasitology, 9(1), 29-31.

Osaki, S. C., Soccol, V. T., Costa, A. O., OliveiraSilva, M. B., Pereira, J. T., \& Procopio, A. E. (2013). Polymerase chain reaction and nested-PCR approaches for detecting Cryptosporidium in water catchments of water treatment plants in Curitiba, State of Paraná, Brazil. Journal of the Brazilian Society of Tropical Medicine, 46(3), 270276. doi: 10.1590/0037-8682-0053-2013
Ouakli, N., Belkhiri, A., Lucio, A. de, Köster, P. C., Djoudi, M., Dadda, A., Carmena, D. (2018). Cryptosporidium-associated diarrhoea in neonatal calves in Algeria. Veterinary Parasitology Regional Studies and Reports, 12(1), 78-84. doi: 10.1016/j. vprsr.2018.02.005

Rahman, M., Uddin, M., Sultana, R., Moue, A., \& Setu, M. (2013). Polymerase chain reaction (PCR): a short review. Anwer Khan Modern Medical College Journal, 4(1), 30-36. doi: 10.3329/akmmcj.v4i1.13682

Razakandrainibe, R., Diawara, E. H. I., Costa, D., Le Goff, L., Lemeteil, D., Ballet, J. J., Favennec, L. (2018). Common occurrence of Cryptosporidium hominis in asymptomatic and symptomatic calves in France. PLoS Neglected Tropical Diseases, 12(3), e0006355. doi: 10.1371/ journal.pntd.0006355

Reif, J. S., Wimmer, L., Smith, J. A., Dargatz, D. A., \& Cheney, J. M. (1989). Human cryptosporidiosis associated with an epizootic in calves. American Journal of Public Health, 79(11), 1528-1530. doi: 10.2105/ajph.79.11.1528

Rigo, C. R., \& Franco, R. M. (2002). Comparison between the modified Ziehl-Neelsen and Acid-Fast-Trichrome methods for fecal screening of Cryptosporidium parvum and Isospora belli. Journal of the Brazilian Society of Tropical Medicine, 35(3), 209-214. doi: 10.1590/s003786822002000300002

Robertson, L. J., Björkman, C., Axén, C., \& Fayer, R. (2014). Cryptosporidiosis in Farmed Animals. In S. M. Cacciò, \& G. Widmer (Eds.), Cryptosporidium: Parasite and Disease (pp. 149-235). Springer, Viena. doi: 10.1007/978-3-7091-1562-6_4. 
Retrieved from https://www.ncbi.nlm.nih. gov/pmc/articles/PMC7122230/pdf/9783-7091-1562-6_Chapter_4.pdf

Robertson, L. J., Johansen, Ø. H., Kifleyohannes, T., Efunshile, A. M., \& Terefe, G. (2020). Cryptosporidium infections in Africa how important is zoonotic transmission? A review of the evidence. Frontiers in Veterinary Science, 7(1), 724. doi: 10.3389/fvets.2020.575881

Roy, S. L., DeLong, S. M., Stenzel, S. A., Shiferaw, B., Roberts, J. M., Khalakdina, A., Beach, M. J. (2004). Risk factors for sporadic cryptosporidiosis among immunocompetent persons in the United States from 1999 to 2001. Journal of Clinical Microbiology, 42(7), 2944-2951. doi: 10.1128/JCM.42.7.2944-2951.2004

Ryan, U., Fayer, R., \& Xiao, L. (2014). Cryptosporidium species in humans and animals: current understanding and research needs. Parasitology, 141(13), 1667-1685. doi: 10.1017/S003 1182014001085

Santín, M., Trout, J. M., \& Fayer, R. (2008). A longitudinal study of cryptosporidiosis in dairy cattle from birth to 2 years of age. Veterinary Parasitology, 155(1-2), 15-23. doi: 10.1016/j.vetpar.2008.04.018

Santín, M., Trout, J. M., Xiao, L., Zhou, L., Greiner, E., \& Fayer, R. (2004). Prevalence and age-related variation of Cryptosporidium species and genotypes in dairy calves. Veterinary Parasitology, 122(2), 103-117. doi: 10.1016/j.vetpar.2004.03.020
Teixeira, C. S., Almeida, A. J. de, \& Oliveira, F. C. R. de. (2008). Oocistos de Cryptosporidium spp. isolados de bezerros bovinos: Pleomorfismo em relação à metodologia de diagnóstico. Journal Brazilian Veterinary Parasitology, 17(1), 230-233.

Thomson, S., Hamilton, C. A., \& Hope, J. C. (2017). Bovine cryptosporidiosis: impact, host parasite interaction and control strategies. Veterinary Research, 48(42), 1-16. doi: 10.1186/s13567-017-0447-0

Wegayehu, T., Karim, R., Anberber, M., Adamu, H., Erko, B., \& Zhang, L. (2016). Prevalence and genetic characterization of Cryptosporidium species in dairy calves in central Ethiopia. PLOS ONE, 11(5), e0154647. doi: 10.1371/journal. pone.0154647

Xiao, L. (2010). Molecular epidemiology of cryptosporidiosis: an update. Experimental Parasitology, 124(1), 80-89. doi: 10.1016/j.exppara.2009.03.018

Xiao, L., Escalante, L., Yang, C., Sulaiman, I., Escalante, A. A., Montali, R. J., Lal, A. A. (1999). Phylogenetic analysis of Cryptosporidium parasites based on the small-subunit rRNA gene locus. Applied an Environmental Microbiology, 65(4), 1578-1583. doi: 10.1128/AEM.65.4.15781583.1999

Xiao, L., Sulaiman, I. M., Ryan, U. M., Zhou, L., Atwill, E. R., Tischler, M. L., Lal, A. A. (2002). Host adaptation and host-parasite coevolution in Cryptosporidium:implications for taxonomy and public health. International Journal for Parasitology, 32(14), 1773-1785. doi: 10.1016/s00207519(02)00197-2 
